\title{
Assessment of physical habitat modification in the Bílina River Basin
}

\author{
Milada Matoušková ${ }^{1, *}$ and Martin Dvořák ${ }^{2}$ \\ ${ }^{1}$ Department of Physical Geography and Geoecology, Faculty of Science, Charles University in Prague. \\ 2 North-Bohemian Water Supply Company. \\ * Corresponding author: matouskova.m@wo.cz
}

Received: $15 / 3 / 2010$

Accepted: 26/4/2011

\begin{abstract}
Assessment of physical habitat modification in the Bílina River Basin

The improvement of the ecological status of many heavily modified water bodies in Europe is a priority of the European Water Framework Directive. This paper evaluates the physical river habitat quality of the Bílina River, one of the most polluted and heavily modified rivers in Central Europe that is mainly classified as a heavily modified WB. The physical river habitat was evaluated using the Ecomorphological River Habitat method (EcoRivHab) and the LAWA Overview Survey method (LAWA-OS). The EcoRivHab method uses field surveys as data input in which the hydromorphological status is determined by 31 parameters, while LAWA-OS is based on the assessment of 17 parameters using available data and mapping resources. Human activities that affect the Bílina River are primarily the expanding coal mining operation and chemical industry, which negatively influence physical river habitat condition. The majority of the reaches of the Bílina River have become embedded, straightened and reinforced, with almost no natural vegetation in the riparian zone. Based on the results of this study, the Bílina catchment was identified as having a strong anthropogenic impact, primarily due to the high amount of reaches in ecological class (EC) IV (20.5 \% EcoRivHab; $34 \%$ LAWA-OS) and V (27.8\% EcoRivHab; $29 \%$ LAWA-OS). These reaches were located in urban and mining areas. Significantly lower proportions of reaches were classified in EC I (2.5\% EcoRivHab; $7.5 \%$ LAWA-OS) and II (9.5\% EcoRivHab; 7 \% LAWA-OS), which are located on the upper course of the Bílina River. Differences between methods in the hydromorphological evaluations are caused by a variety of observed parameters, including different delimitations of river zones and widths of the scoring intervals. This study demonstrated the possibility of applying both methods in assessing heavily modified and artificial water bodies.
\end{abstract}

Key words: LAWA-OS, EcoRivHab, River habitat, Hydromorphology, Modification, Coal mining, Bílina River, Czech Republic.

\section{RESUMEN}

\section{Evaluación de las modificaciones del hábitat físico en la cuenca del río Bílina}

La mejora del estado ecológico de muchas masas de agua muy modificadas en Europa es una petición de la Directiva Marco del Agua-DMA. En este trabajo se evalúa la calidad del hábitat físico del río Bílina, uno de los ríos más contaminados y modificadas, en Europa Central, el cuál ha sido clasificado como un cuerpo de agua muy modificado. El hábitat del río Bílina se evaluó mediante el método "Ecomorphological River Habitat" (EcoRivHab) y el método "LAWA Overview Survey method" (LAWA-OS). El método EcoRivHab utiliza datos de muestreo sobre el terreno y el estado hidromorfológico se determina mediante 31 parámetros, mientras que LAWA-OS se basa en la evaluación de 17 parámetros utilizando los datos disponibles y la asignación de recursos. La actividad humana en el río Bílina está representada sobre todo por la expansión de la industria minera del carbón y química que influyen negativamente en la condición física del hábitat fluvial. La mayoría de los tramos del río Bílina se han dragado, enderezado y reforzado quedando muy poca vegetación natural en la zona ribereña. En base a los resultados obtenidos, es posible identificar la cuenca del río Bílina con un fuerte impacto antropogénico, principalmente debido a la gran cantidad de tramos en la clase ecológica (CE), IV (20.5\% EcoRivHab; $34 \%$ LAWA-OS) y la CE V (27.8\% EcoRivHab y el $29 \%$ de LAWA-OS). Estos tramos fluviales estaban principalmente ubicados en zonas urbanas y mineras. Una cantidad significativamente menor se clasificaron dentro de la CE I (2.5 \% EcoRivHab; $7.5 \%$ LAWA-OS) y CE II (9.5\% EcoRivHab; 7 \% LAWA-OS), encontrándose estos en el curso superior del río Bílina. Las diferencias en los resultados de la evaluación hidromorfológica entre los métodos utilizados son causadas por una variedad de parámetros observados, la 
delimitación de las diferentes zonas del río y la amplitud de los intervalos de puntuación. El estudio demostró la posibilidad de aplicar ambos métodos para evaluar cuerpos de agua muy modificados y artificiales.

Palabras clave: LAWA-OS, EcoRivHab, Hábitat fluvial, Hidromorfología, Modificación, Minería del carbón, Río Bílina, República Checa.

\section{INTRODUCTION}

Many European river catchments and water bodies have been altered by human activities, such as land drainage, dredging, flood protection, water abstraction and inter-basin water transfer, the building of dams to create reservoirs and the digging of new canals for navigation purposes. Human impacts on stream systems often result in the simplification of their geomorphological structure and hence reduced biodiversity (Semeniuk 1997 in Xia et al., 2010). Human alterations also cause substantial habitat degradation and reduce the ecological value of the supported biological communities in the streams (Brookes, 1988, Paul \& Meyer 2001).

In some cases, The Water Framework Directive (WFD) recognises that human uses of the water bodies are beneficial and need to be retained. If a series of criteria are fulfilled, it allows designation of the surface water body (SWB) as "artificial" (AWB) or "heavily modified" (HMWB), which has been done for bodies of water such as reservoirs, canals or canalised rivers. HMWBs are bodies of water that, as a result of physical alterations by human activity, are substantially changed in character and therefore cannot meet "good ecological status" (GES). In this context, physical alterations mean changes to, for example, the size, slope, discharge, form or shape of the river bed. AWBs are surface water bodies that have been created in a location where no WB existed before and that have not been created by the direct physical alteration, movement or realignment of an existing WB (EC, 2000).

According to the Water Framework Directive (EC, 2000), all member states shall protect, enhance and restore all bodies of surface water, including artificial and heavily modified water bod- ies, with the main aim of achieving good surface water status or potential by 2015 at the latest (EC, 2000). The specifications used for stipulating when a SWB is to be designated as heavily modified are described in Art.4(3) and Annex V of the WFD. This classification is done by first subdividing all water bodies into 4 groups: no HMWB ("natural SWB"), candidates for HMWB, HMWB and AWB. If the SWB has a reliable status, it is to be classified as "natural". Otherwise, 2 steps are carried out to classify HMWB:

- Step 1: Is it possible to achieve GES by means of hydromorphological restoration measures without significant adverse effects on the HMWB-relevant uses or the wider environment?

- Step 2: Is it possible to achieve a good ecological status by other suitable means (without incurring disproportionate costs and provided that they are technically feasible)?

If the answer to the two above questions is "no", the SWB is classified as a HMWB, and the environmental objective applicable to both HMWBs and AWBs is not GES but "good ecological potential" (GEP; EC, 2000). However, it is important to appreciate that the identification and designation of HMWBs and AWBs are not a onetime process, but that the WFD allows a certain degree of flexibility to modify designations so that changes over time in environmental, social and economic circumstances can be taken into account (CIS, 2003).

The current situation regarding European heavily modified water bodies is presented by Kampa \& Hansen (2004), who carried out their study in the context of the Common Implemen- 
tation Strategy of the EU WFD. Their study focused on methods used in 12 European countries in identifying HMWBs and AWBs, in which 28 case studies dealt with river ecosystems. Despite this effort, the final document on HMWBs and AWBs (WFD CIS Guidance Document No. 4, 2003) did not include specific guidance on methods to be used for the identification of HMWBs and AWBs nor on which should be used to assess GEP in these water bodies. Therefore, further research on the identification of HMWBs and AWBs and assessment of GEP is needed. On the other hand, other initiatives, such as the identification and delimitation of HMWBs in the Czech Republic (Aquaplus et al., 2004), have formulated more specific methods. In this case, the identification of HMWBs is performed by the examination of six characteristics: (1) piped reaches, (2) course modification, (3) back waters, (4) combined assessment of river modification, (5) discharge regulation and (6) water withdrawals.

The number of rivers highly modified in $\mathrm{Eu}-$ rope is quite large. The Netherlands, Belgium, Slovakia and the Czech Republic have classified more than $50 \%$ of their water bodies as a HMWB or AWB, while other EU Member States have on average $16 \%$ of their water bodies classified as a HMBW or AWB (EEA, 2010). A more complete overview of Europe's modified waters will be generated in the coming years through River Basin Management Plans reporting (EEA, 2010). Moreover, the Rhine and Danube Rivers (the two largest European rivers) have lost $85 \%$ and $95 \%$ of their floodplains, respectively, through channel straightening, river dykes and drainage for different purposes (Schneider, 2010 in Eiseltová, 2010). Thus, it is extremely important that the EU Member States have a standardised and reliable methodology for classifying water bodies as a SWB, HMWB or AWB and for assessing GEP for HMWBs and AWBs.

In this study, we concentrated on the Bílina River catchment, which is one of the most heavily modified water bodies in the Czech Republic. The ecological status of the Bílina River is heavily modified, and it urgently requires a solution in conforming to strategies of sustainable develop- ment and the WFD (EC, 2000). Our main objective is to assess the hydromorphological quality of the Bílina River with different methods, including using a field survey as well as processing available data sources (Matoušková, 2008b). The two methods chosen were the Ecomorphological River Habitat method (EcoRivHab; Matoušková, 2003, 2007) and LAWA Overview Survey method (LAWA-OS; Kern et al., 2002). The EcoRivHab method was chosen because it has been applied to more than $400 \mathrm{~km}$ of river in the Czech Republic in the detailed hydromorphological survey of streams, while the LAWA-OS was chosen because it is a method frequently used in neighbouring countries of the Czech Republic (e.g., Germany). None of these methods were designed specifically for the assessment of hydromorphological quality of HMWBs and AWBs; however, we were interested in determining their performance on this type of WB.

\section{METHODOLOGY}

\section{Study area: The Bílina River catchment}

The Bílina River is a significant tributary of the Elbe River with a catchment area of $1070.9 \mathrm{~km}^{2}$, draining the northwestern part of the Czech Republic. The Bílina River springs at $785 \mathrm{~m}$ a.s.l. in the Krušné hory (Ore Mountains). The length of the main stream before reaching the Elbe River in the city of Ustí nad Labem is $80.5 \mathrm{~km}$. The catchment is mainly composed of granite and basalts rocks. Dominant soil types are cambisols, podzols and anthrozems. Streams flowing from the Krušné hory Mts. are characterised by steep inclines with predominant erosive processes and sediment load. These natural hydromorphological processes are greatly influenced by significant river modification.

From a climatic point of view, only the highest river reaches (on the ridge of Krušné hory Mts.) belong to a cold area (CH7; Quitt, 1971), where average annual air temperatures range from 5 to $6{ }^{\circ} \mathrm{C}$ and the average annual precipitation fluctuates between 900 and 1,200 mm (Tolasz, 2007). The climate in the Mostecká catchment is part of 
a warm area (T; Quitt 1971), where the average air temperature is between 9 and $10^{\circ} \mathrm{C}$ (Tolasz, 2007). The remaining parts of the catchment belong to a moderately warm area (MT1 and MT4; Quitt, 1971), with an average annual temperature between 6 and $8{ }^{\circ} \mathrm{C}$, precipitation between 450 and $800 \mathrm{~mm}$ and a strong gradient from southwest to northeast (Tolasz, 2007). The mean annual precipitation in the Bílina River Basin is 634 mm (Š́pek et al., 2010), with the highest values achieved during summer thunderstorms.

The hydrologic regime of the Bílina River has also been significantly influenced by human activity over the past several decades. Mine protection from floods has required the construction of numerous water translocations such that a significant part of the water in the catchment is made up of water transfers from neighbouring basins (Ohře River and Flájský Creek). One of the most significant water management projects was the translocation of the Bílina River over the Ervěnický Corridor using four steel pipes, each $4 \times 1200 \mathrm{~mm}$, with a total length of
3193 m (Povodí Ohře, 1986). The natural hydrological regime was preserved only on the upper course above the water reservoir Jirkov (Vlasák, 2004). The average annual discharge is $6.84 \mathrm{~m}^{3} \mathrm{~s}^{-1}$ in the Trmice gauging station (19952006), while the long-term specific discharge is $6.39 \mathrm{ls}^{-1} \mathrm{~km}^{-2}$, and the average discharge coefficient is $33.2 \%$ (Vlasák, 2004). The hydrographs are characterised by a maximum in March or April during the spring thawing of the snow and minimums during the summer months.

Other significant anthropogenic modifications of and interference with the landscape of the Bílina River Basin include the drainage of the largest fluvial lake in Bohemia, Komořanské Lake (5600 ha), which began in the $19^{\text {th }}$ century. In total, during an 80-year time period, the Bílina River channel has been reduced by nearly $3.9 \%$. This value is low because it consists of both the reduction as well as the extension of the river length (Fig. 1). Finally, nowadays, more than $20 \%$ of the catchment comprises residential, industrial and mining land uses, while agri-

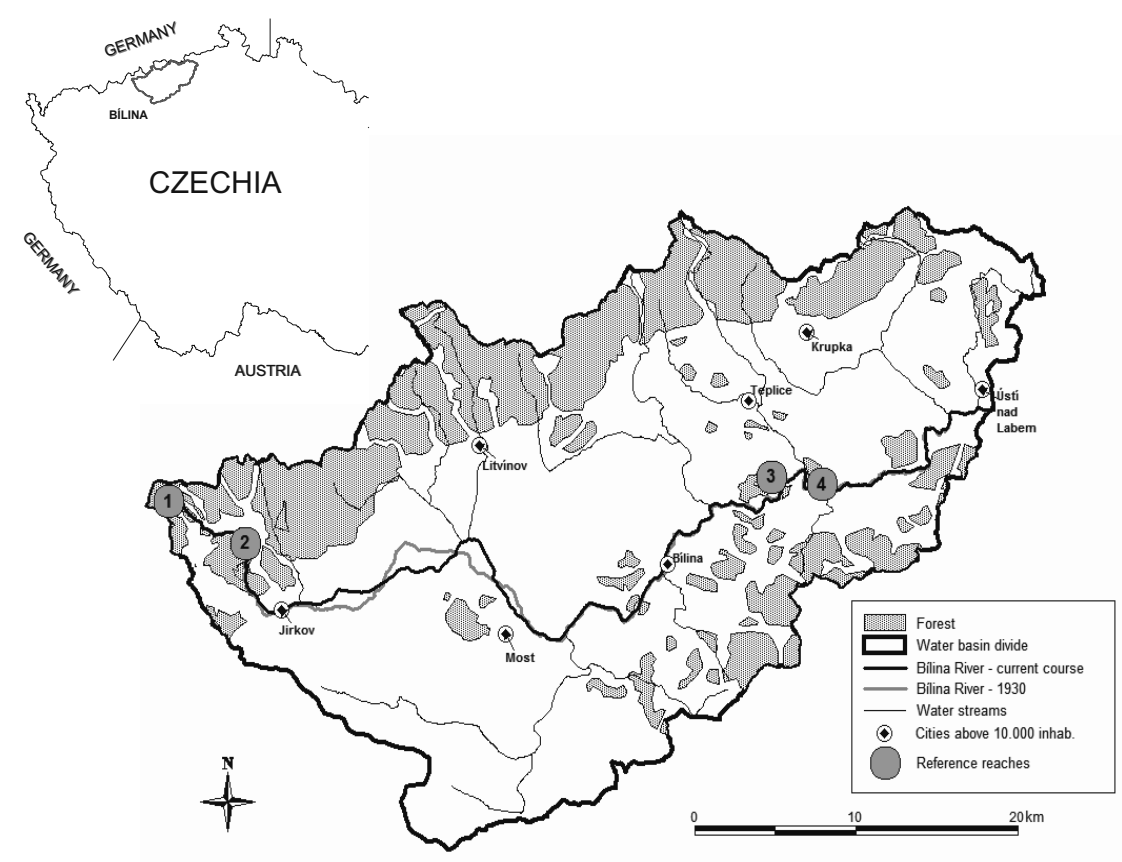

Figure 1. Location of the Bílina River Basin, anthropogenic modification of the main stream and reference reaches for the assessment of hydromorphological quality. Localización de la Cuenca del Río Bílina, modificaciones antropogénicas en el eje principal y tramos de referencia para la evaluación de la calidad hidromorfológica. 
cultural land uses and forests account for over $40 \%$ and $30 \%$ of the catchment area, respectively. The original forests in the Krušné hory Mts. were mostly cleared during intensive mining and ore processing and later replaced with forestry monocultures.

\section{Applied methods and data sources}

The assessment of the hydromorphological quality of the Bílina River $(80.5 \mathrm{~km})$ was performed using EcoRivHab (Matoušková, 2003, 2007) based on a detailed field survey and LAWAOverview Survey (LAWA-OS; Kern et al., 2002) based on the processing of available data, such as information from water basin authorities (e.g., type of river modification, discharges, old and recent aerial images and historical and recent topographic maps).

Both methods assess hydromorphological conditions by classifying river reaches in a 5degree scoring system, in accordance with the requirements of the WFD. Moreover, both methods divide river zones into three well-defined areas, although the definition of these zones is different (Table 1). The EcoRivHab method distinguishes the channel (stream bed + banks), the zone of riparian belts and the floodplain zone, while the LAWA-OS method outlines the stream bed zone, bank zone and the zone of the adjacent land (riparian belt + partly floodplain). Another notable difference between the methods is that the EcoRivHab method allocates the same weight to each individual zone for the final assessment, while the LAWA-OS method focuses on the discharge capacity of the cross profile section, the character of the flow and the connection to groundwater bodies in the channel zone (stream bed + banks). Likewise, EcoRivHab focuses in greater detail on the structure and composition of the riparian vegetation and floodplain land use.

\section{The LAWA-OS method}

This method was selected because it was tested in a selection of river reaches in the Elbe River in the Czech Republic (Fuksa, 2000) and is reg- ularly used in the neighbouring State of Saxony and in its modified form in Slovakia (Pedersen $e t$ al., 2004, Adamková et al., 2004). Moreover, this method can use all available information, including recent aerial images (scale 1:5000 to 1:15 000, not older than 5 years), historical aerial images and historical and recent topographic maps (scale 1:25 000) or other thematic maps (Table 1).

The LAWA-OS (Kern et al., 2002) method is based on the assessment of 17 features using data collected for fixed reaches of 500 or $1000 \mathrm{~m}$ in distance. Nine single features aggregated to two main parameters, river bed and floodplain dynamics, have to be recorded (LAWA, 2002; Kamp et al., 2004). Features of river bed and floodplain dynamics are derived from an interpretation of recent aerial images (scale 1:5000 to $1: 15000$, not older than 5 years), historical aerial photographs, historical and recent topographic maps (scale 1:25 000) or other thematic maps. Local expert knowledge provides information concerning the possibility of water flow across the floodplain and artificial barriers (LAWA, 2002 in Weiss et al., 2008). Data processing and the calculation of scores and the final index are described in depth elsewhere (Kamp et al., 2005). The classification system of LAWA-OS uses hierarchical criteria such that the recorded features do not have the same indicative power. Some features (e.g., curvature or potential for structure formation) are so-called highly integrative parameters. These characteristics are rated higher than others, such as the existence of bank vegetation. The index system also follows the rule that a chain is only as strong as its weakest link, which explains the following principle: it is not possible to compensate for poor riverbed dynamics by good floodplain dynamics (Kamp et al., 2005; Weiss et al., 2008).

\section{The EcoRivHab method}

This method uses a field survey as the input data source (Matoušková 2003, 2007). However, the use of aerial images and historical and recent topographic maps could also be considered. Hydromorphological quality is calculated on the basis of 31 parameters, which are separated into 
Table 1. Features of LAWA-OS (Kern et al., 2002) and EcoRivHab methods (Matoušková, 2007) used to evaluate hydromorphological quality (x indicates "not included"). Características de los métodos LAWA-OS (Kern et al., 2002) y EcoRivHab (Matoušková, 2007) utilizados para evaluar la calidad hidromorfológica (x representa características no consideradas).

\begin{tabular}{|c|c|c|c|}
\hline $\begin{array}{l}\text { Assessment } \\
\text { categories }\end{array}$ & $\begin{array}{l}\text { Generic features } \\
\text { EN } 14614\end{array}$ & $\begin{array}{l}\text { Parameters } \\
\text { LAWA-OS }\end{array}$ & $\begin{array}{l}\text { Parameters } \\
\text { EcoRivHab }\end{array}$ \\
\hline \multicolumn{4}{|c|}{ Stream bed + banks (LAWA-OS) and Channel (EcoRivHab) } \\
\hline \multirow[t]{3}{*}{ Geometry } & Plan form & Curvature & $\begin{array}{l}\text { Curvature and braiding, channel character and shape } \\
\text { (modification) }\end{array}$ \\
\hline & Longitudinal section & $\mathrm{X}$ & Occurrence of natural and artificial steps \\
\hline & Cross-section & Depth variation & $\begin{array}{l}\text { Deepening of the channel, stability of the profile, } \\
\text { mean depth, width and depth variation (occurrence } \\
\text { of riffles and pools), dimension of the profile }\end{array}$ \\
\hline \multirow[t]{2}{*}{ Structures } & Artificial substrate types & Stream bed structures & Bed-fixing \\
\hline & Natural substrate types & $\mathrm{X}$ & Type of substrate \\
\hline \multirow[t]{3}{*}{$\begin{array}{l}\text { Vegetation and Organic } \\
\text { debris }\end{array}$} & $\begin{array}{l}\text { Structural form of } \\
\text { macrophytes present }\end{array}$ & $\mathrm{X}$ & Macrophytes \\
\hline & $\begin{array}{l}\text { Leafy and woody debris, } \\
\text { occurrence of special } \\
\text { structures }\end{array}$ & Death trees & Diversity of microhabitats including death trees \\
\hline & $\begin{array}{l}\text { Features in channel and at } \\
\text { base of bank }\end{array}$ & $\mathrm{X}$ & Erosion and accumulation forms \\
\hline $\begin{array}{l}\text { Erosion/deposition } \\
\text { character }\end{array}$ & Flow patterns & $\mathrm{X}$ & Character of flow \\
\hline \multirow[t]{2}{*}{ Flow } & Flow features & $\mathrm{X}$ & $\begin{array}{l}\text { Diversity of microhabitats, depth variability } \\
\text { (occurrence of riffles and pools) }\end{array}$ \\
\hline & Discharge regime & Discharge regulation & Human-made changes in flow regime \\
\hline $\begin{array}{l}\text { Longitudinal continuity as } \\
\text { affected by artificial } \\
\text { structures }\end{array}$ & $\begin{array}{l}\text { Artificial barriers } \\
\text { affecting continuity of } \\
\text { flow, sediment transport } \\
\text { and migration for biota }\end{array}$ & Migration barriers & Occurrence of artificial steps \\
\hline \multirow[t]{2}{*}{$\begin{array}{l}\text { Bank structures and } \\
\text { modifications }\end{array}$} & Bank profiles & $\begin{array}{l}\text { Depth erosion (without } \\
\text { indicative power) }\end{array}$ & Bank erosion, Stability of the profile \\
\hline & Structure of vegetation & Bank vegetation & Bank vegetation \\
\hline \multicolumn{4}{|c|}{ Adjacent land (LAWA-OS) and Riparian belt (EcoRivHab) } \\
\hline \multirow[t]{2}{*}{ Vegetation type/structure } & Vegetation strips & $\begin{array}{l}\text { Existence and extent of } \\
\text { vegetation strips }\end{array}$ & $\begin{array}{l}\text { Existence and extent of vegetation strips } \\
\text { Structure of vegetation strips }\end{array}$ \\
\hline & $\begin{array}{l}\text { Types of land-use, and } \\
\text { types of development }\end{array}$ & Land use & Land use \\
\hline
\end{tabular}

\begin{tabular}{llll}
\hline & \multicolumn{1}{c}{ Adjacent land (LAWA-OS) and Floodplain (EcoRivHab) } \\
\hline $\begin{array}{l}\text { Adjacent land-use and } \\
\text { associated features }\end{array}$ & $\begin{array}{l}\text { Types of open } \\
\text { water/wetland features }\end{array}$ & Retention of the floodplain \\
\hline & $\begin{array}{l}\text { Degree of constraint to } \\
\text { potential mobility of river } \\
\text { channel and water flow } \\
\text { across the floodplain }\end{array}$ & Flood protection measures & Flood protection measures \\
\hline $\begin{array}{l}\text { Degree of (a) lateral } \\
\text { connectivity of river and } \\
\text { floodplain; (b) lateral } \\
\text { movement of river channel }\end{array}$ & Continuity of floodplain & $\begin{array}{l}\text { Possibility of water } \\
\text { flowing across the } \\
\text { floodplain }\end{array}$ & $\mathrm{X}$ \\
\hline $\begin{array}{l}\text { Additional } \\
\text { nand }\end{array}$ & & & $\begin{array}{l}\text { River valley type, Connection to groundwater bodies, } \\
\text { sewage outlets, water quality (not necessary), land } \\
\text { use of the floodplain }\end{array}$ \\
\hline
\end{tabular}


the following three monitoring zones: channel, riparian belt and floodplain. Reaches of heterogeneous lengths are used for the calculation, but it is recommended not to use reaches longer than $1 \mathrm{~km}$. Delimitation of reaches is based on the homogeneous nature of major physical habitat features, such as river course, river bed modification, land use of riparian zones and land cover of alluvial plains.

Field assessment of river bed hydromorphological structures should be performed during low-flow conditions and before the maximum vegetation growth. In this study, field data were gathered from August to September 2009. Surveyors can use available mapping information to assess some variables (Table 1). All recorded information is mapped and processed to convert the results into thematic geographic information system (GIS) layers by means of identifiers. The calculation of sub-indexes and a final index is based on an additive principle, meaning that every parameter and every observed zone have the same weight. A detailed description of the EcoRivHab method, data collection during the field survey, data processing and calculation of the sub-final and final indexes is presented in Matoušková (2008a).

The definition of "reference sites" is needed for the application of the EcoRivHab method. The upper course of the Bílina River has a near natural habitat. At the inlet into the Mostecká Basin, the number of natural reaches decreases to nearly zero, and the anthropogenic impact significantly increases. Four locations, where near natural conditions exist or are prevailing, were chosen in the Bílina River as reference reaches (Figure 1). Two locations in the Krušné hory Mts. have natural conditions, including an area of a plateau (79.6-80.5 r. km) and an area of the Telšské Valley $(72.6-74$ r. km). Two other reaches on the lower course of the České středohoří Mountain Range between the towns of Lysec and Lbín (21.7-22.1 r. km) and further through a segment between Sezemice and Rtyně (15.4-16.3 r. km) were also used as examples of near natural conditions.

The comparison between the two applied methods, EcoRivHab and LAWA-OS, was performed by (1) calculating the overlap of total eco- hydromorphological status on the upper, middle and lower course, (2) using circular division for scores obtained on individual delimited zones for each assessed river reach and (3) calculating the number and percentage of river reaches with similar scoring for each individual river zone, The cartography used for the Bílina River catchment hydromorphological assessment included the Basic topographic map of the Czech Republic 1:25 000; the Basic water management map 1:50 000 (VÚV T.G.M. Prague); the Digital Elevation Model DEM 1:25000 (ČÚZAK Prague); and old topographic maps 1:25 000 that are based on the maps of the $3^{\text {rd }}$ Military mapping of Austria-Hungary Monarchy from the end of $19^{\text {th }}$ century (Map Collection, Faculty of Science, Charles University in Prague). A significant source of data was from the water basin authority Povodí Ohře, which supplied information on the performed modifications.

\section{RESULTS}

\section{EcoRivHab and LAWA-OS comparison}

The EcoRivHab method divided the Bílina River into 133 reaches with an average length of $605 \mathrm{~m}$, and ranging from $69 \mathrm{~m}$ (BIL004) to $3200 \mathrm{~m}$ (BIL036, which represents the piped Ervěnický Corridor, hereinafter referred to as "ERC"). If the ERC is excluded, the longest reach was BIL079, with a total length of $1100 \mathrm{~m}$. River reaches included back waters and water reservoirs that were not assessed with the EcoRivHab method. The LAWA-OS method yielded 161 reaches of $500 \mathrm{~m}$, each covering a total length of $80.5 \mathrm{~km}$.

Comparison of the results of the two methods is possible only for the final hydromorphological condition assessment, as both identify different river reaches and evaluate different characteristics for each considered river zone (Table 1). Among the reaches that are unchanged or slightly changed (EC I and II), both methods yield approximately equal percentages of river length (12\% EcoRivHab, $15 \%$ LAWA). Reaches within EC III and EC IV prevail when using the EcoRivHab method $(55 \%)$, while 


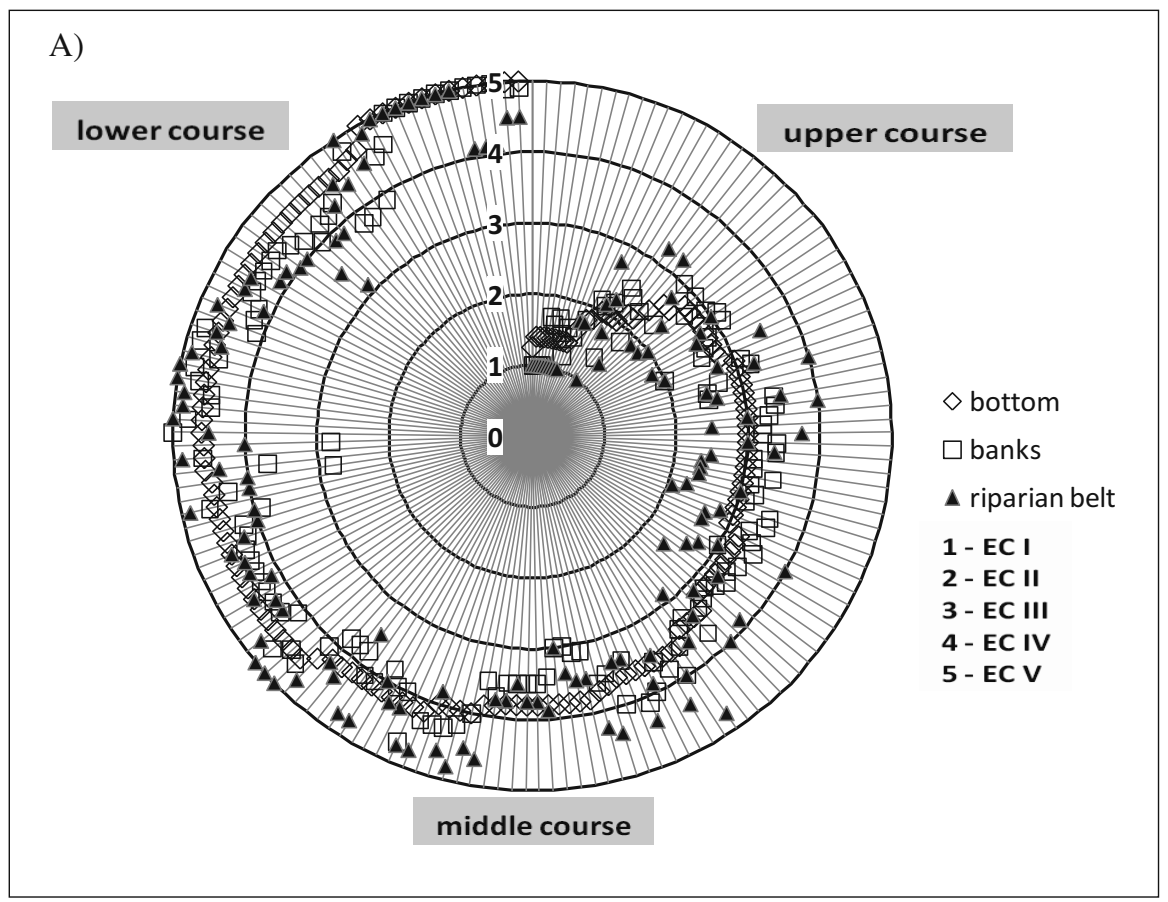

B)

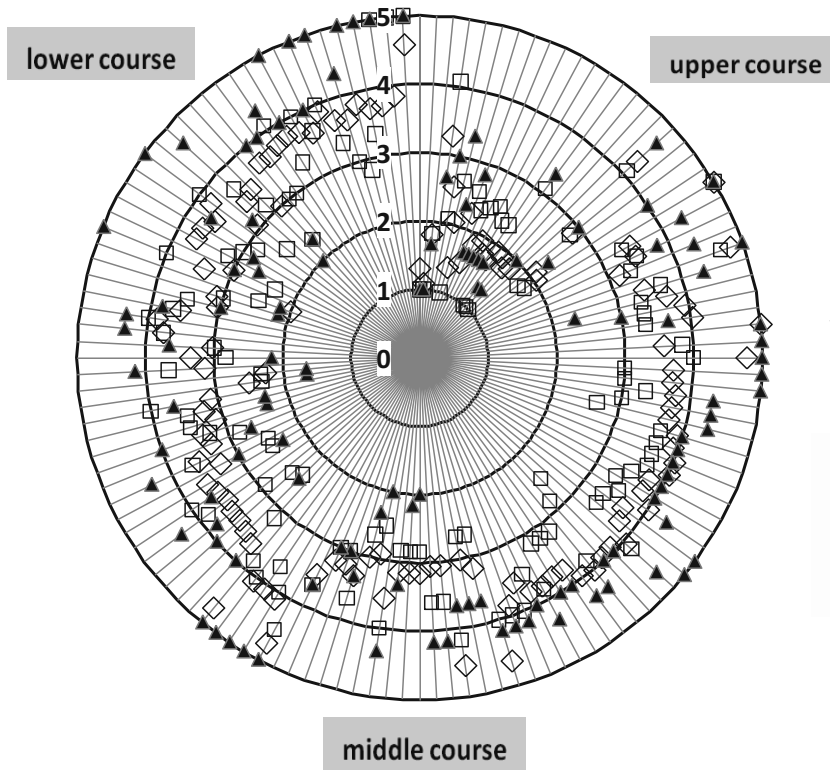

$\diamond$ channel

$\square$ riparian belt

$\Delta$ flood plain

1 - ECI

2 - EC II

3 - EC III

4- ECIV

5 - EC V

Figure 2. Classification of hydromorphological quality of the different delimited river zones using the methods $a$ ) LAWA-OS and b) EcoRivHab. Every line radiating from the centre represents a classified river reach. Obtained quality classification for each zone is drawn with different marks. River reaches are ordered from upstream to downstream in a clockwise direction. Clasificación de la calidad hidromorfológica utilizando las diferentes zonas del río delimitadas por los métodos a) LAWA-OS and b) EcoRivHab. Cada linea que radia del centro representa un tramo de río. La clasificación obtenida para cada zona se dibuja con diferentes símbolos. Los tramos fluviales están ordenados en el sentido de las agujas del reloj para ambos métodos siguiendo el orden desde tramos más altos a tramos más bajos. 
Table 2. Similarity of scoring in the hydromorphological assessment of the different delimited zones when using EcoRivHab and LAWA-OS methods. Similitud en la evaluación hidromorfológica entre las diferentes zonas delimitadas cuando se utilizan los métodos EcoRivHab y LAWA-OS.

\begin{tabular}{lcc|cc}
\hline & \multicolumn{2}{c|}{ EcoRivHab } & \multicolumn{2}{c}{ LAWA-OS } \\
\hline $\mathbf{N}^{\mathbf{0}}$ Reaches & $\begin{array}{c}\text { Similarity } \\
(\boldsymbol{\%})\end{array}$ & $\mathbf{N}^{\mathbf{0}}$ Reaches & $\begin{array}{c}\text { Similarity } \\
(\boldsymbol{\%})\end{array}$ \\
\hline EC I & 2 & 2 & 0 & 0 \\
\hline EC II & 9 & 7 & 4 & 2 \\
\hline EC III & 6 & 5 & 18 & 11 \\
\hline EC IV & 17 & 13 & 14 & 9 \\
\hline EC V & 3 & 2 & 29 & 18 \\
\hline
\end{tabular}

when using the LAWA-OS method, there is a greater proportion in EC IV and V $(63 \%)$ at the expense of EC III (25\%). Thus, LAWAOS seems to evaluate segments that have significant anthropogenic impact more strictly than the EcoRivHab method, which is demonstrated by $29 \%$ of the reaches belonging to EC V according to LAWA-OS compared with less than $8 \%$ according to EcoRivHab.

The evaluations for each of the river zones were more homogeneous when using the LAWAOS method than when using the EcoRivHab method (Fig. 2A and 2B, respectively). River zones were classified with a similar EC score of $40 \%$ of the river reaches when using LAWA-OS in comparison with $29 \%$ when using EcoRivHab (Table 2). The highest degree of similarity was found using the LAWA-OS assessment for the EC V $(18 \%)$ in comparison with EcoRivHab, where the similarity was only $2 \%$. Moreover, riparian belt evaluations using the LAWA-OS method were the most variable of the three zones, while floodplain evaluations using the EcoRivHab method were consistently lower then other zones for almost every single site.

\section{Longitudinal pattern in the Bílina River}

The unchanged reaches (EC I) were located in the spring of the Bílina River and on the upper course of the Bílina River in the Telšské Valley, where natural characteristics accounted for only $2.5 \%$ (EcoRivHab) and $7.5 \%$ (LAWAOS) of the river's total length (Fig. 3). Slightly changed segments (EC II) were located in the mountain area above the Březenec water reservoir. The bank vegetation and the floodplain consisted of forests with unnatural species compositions or fallow land. On the other hand, the middle course was mainly represented by EC IV and V. Substantial river modifications occurred between the cities of Jirkov and Most, where the channel of the Bílina River was translocated due to Ervěnický and Mostecký artificial channels, and in the urban areas of Obrnice and Zlatníky, Bílina and Chudeřice.

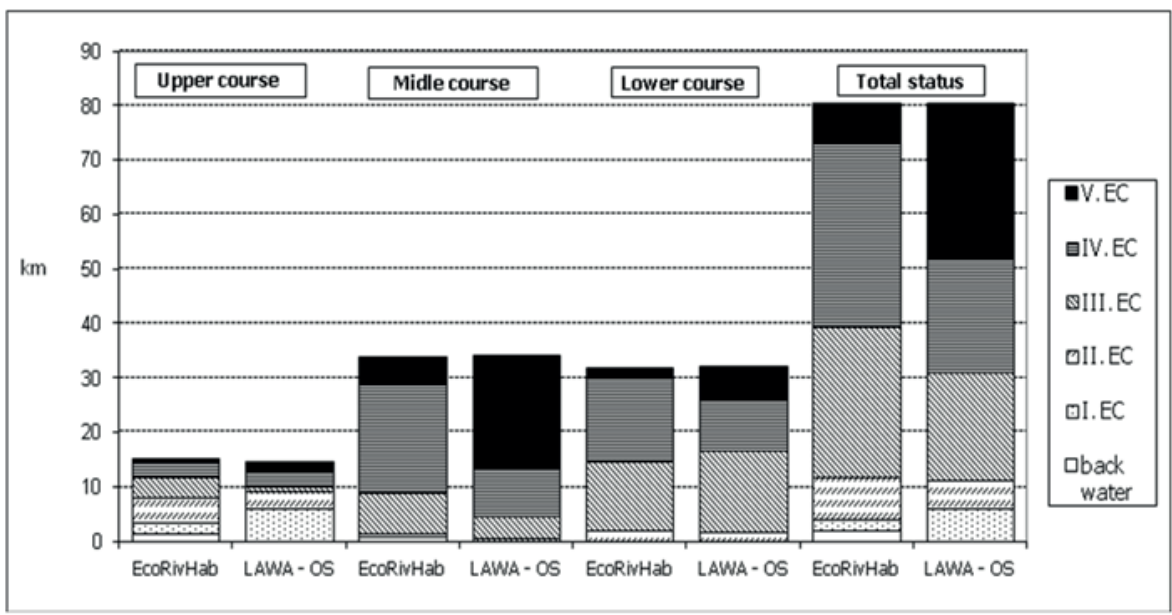

Figure 3. Percentage of river length included in each of the five hydromorphological quality classes (EC I to EC V) using EcoRivHab (left) and LAWA-OS (right) methods on the upper, middle and lower course and on the total course of the Bílina River. Porcentaje de longitud de río incluido en cada una de las cinco clases de calidad hidromorfológica (CE I a CE V) utilizando los métodos EcoRivHab (izquierda) y LAWA-OS (derecha) en los tramos alto, medio y bajo y en el total del río Bílina. 
The lower course was generally represented by river reaches in classes EC III, EC IV and EC $\mathrm{V}$ but that can be divided in two different types of reaches. The first type is composed of river reaches of medium changed status located in rural areas of the České středohoří Mountain Range. These river channels have been deepened and reinforced with sheet pilling, while bank and riparian vegetation are primarily ruderal and is represented by gallery forests and solitary trees. The floodplain is primarily made up of fallow land, generally limited by roads. The second type of river channels were river reaches in urban areas of Trmice and Ústí nad Labem. These river channels have been deepened and reinforced with quarry stone or concrete materials. The riparian zone has been heavily reduced and the flood plain is completely occupied by urban or industrial land uses.

\section{DISCUSSION}

The Bílina River catchment has a poor hydromorphological quality, mainly because of the high proportion of river reaches in quality classes EC IV and V (more than 50\%) and a low proportion of reaches in classes EC I and II (15\%). Moreover, the distribution of river reaches among hydromorphological quality classes followed a spatial pattern related to human activity and floodplain land uses. The application of both LAWA-OS and EcoRivHab methodologies to establish the GEP of HMWBs seems possible, although some important considerations should be taken into account in future developments.

\section{Hydromorphological quality in the Bílina River}

The Bílina River catchment well represents the geographic and topographic diversity of the Czech Republic, and is a good example of a heavily modified river ecosystem of the Czech Republic. A nearby river, the Rolava River, can serve as a comparable catchment that also drains Krušné Hory Mt. This river can be described as a moderately impacted river with reaches of EC I and II, representing $40 \%$ of the river length.
These river reaches were concentrated on the upper courses, as in the present study, while river reaches of quality EC IV and V (12\%) were concentrated on the middle course (Nejdek city) and on the lower course (Karlovy Vary; Matoušková et al., 2010), repeating a similar pattern as with the Bílina River. This spatial pattern in which river modification is more severe with the increase of urban and industrial activities is a wellrecognised pattern (Xia et al., 2010, Langhammer, Matoušková, 2006).

The improvement of the current status of the Bílina River is very difficult because modified reaches are located in urban, industrial and mining areas with ongoing human activities. The changes in the physical river habitat are related to totally changed fluvio-morphological processes and hydrological regimes. Both applied methods compare individual evaluated parameters to a predetermined reference status, but the definition and location of reference reaches in the Bílina catchment and nearby catchments is very difficult. For example, no reference reaches could be delimited on the middle course because of strong landscape transformations, while on the lower course, river reaches do not fulfil the requirement of EC I quality class, although they represent EC II. Therefore, the establishment of a GEP on which to base river management and restoration activities might need to come from the theoretical reconstruction of sensible scores for each of the river zones evaluated using each of the two methods used in this study (EC, 2000).

\section{Comparison of the two methods}

Both methods used in this study were able to identify heavily modified reaches. The LAWAOS seems to be stricter because of the minimum principle and is mainly focused on river bed dynamics. The EcoRivHab method observed more parameters of the riparian belt and floodplain, meaning that the natural and near natural vegetation strips positively influenced the final eco-hydromorphological class. The main differences between the methods were in reach length, the number of observed parameters, data acquisition method, the delimitation of river zones and 
the calculation of the final quality status. The LAWA-OS method recommends defining homogeneous reaches of the same length. This allows for precise quantification of the occurrence of individual characteristics. On the contrary, the EcoRivHab method allows for the evaluation of reaches of variable lengths. This speeds up the terrain survey because it allows qualitatively homogeneous sections to be evaluated (e.g., reaches with the same bank reinforcement type). However, the frequency of occurrence of certain characteristics can only be carried out in terms of relative quantity (i.e., high, medium, low frequency). In the case of the EcoRivHab method, all parameters have the same descriptive quality, and the resulting quality class is calculated based on the arithmetic average (i.e., a single negative characteristic does not fundamentally affect the resulting ecological state). The applied LAWAmethod uses hierarchical criteria, which means that recorded features do not have the same indicative power (Weiss et al., 2008).

Regarding other considerations such as time, existing knowledge, data demand and the level of generalisation, the LAWA-OS method is better when the lowest time and knowledge are required because it is based on the assessment of 17 parameters without the need for field surveys; however, the level of generalisation is relatively high, and the quality of the results is strictly dependent on the quality of existent datasets. On the other hand, the EcoRivHab method has higher data demands, and data processing is time consuming.

Finally, more than 25 different methods for assessing different hydromorphological characteristics of rivers currently exist in Europe (Fernandez et al., 2011). The use of so many different principles might produce different results, and more so under various landscapes or climates. The comparison of different methods in the European Union and elsewhere should be examined in depth, and a common methodology, or at least a definition of the most important characteristics to record, should be agreed upon (e.g., CEN 2002). This could form a basis for comparing studies on river physical habitats at a large scale and could help to define an approach to calculating hydromorphological quality classes.

\section{CONCLUSIONS}

The survey results demonstrated that the EcoRivHab and LAWA-OS methods could be applied to heavily modified and artificial water bodies in anthropogenically transformed fluvial landscapes. In the overall evaluation of hydromorphological quality, the LAWA-OS method has a preference for river bed dynamics using the assessment parameters of curvature, stream bed stability, width variability, bank impairments and the retention capability of the floodplain. The EcoRivHab method observes the vegetation belt in two delimited zones, riparian belt and floodplain, meaning that the natural or near natural character of the vegetation belt has a positive influence on the total eco-hydromorphological status. The hydromorphological condition of the Bílina River habitat is poor, with more than $50 \%$ of its river reaches in EC IV and V quality classes, according to both methods employed (the LAWA-OS method indicates over $60 \%$ ). The obtained results for the Bílina River could be used as a benchmark to detect changes in river habitat characteristics.

\section{ACKNOWLEDGEMENTS}

We gratefully thank the Czech Ministry of Environment for their generous support with the research project "Negative human impacts in the Bílina River Basin (SP/1b7/124/08)". The research was also supported by the Czech Ministry of Education (MSM 0021620831) for the project "Geographical systems and risk processes in the context of global changes and European integration".

\section{REFERENCES}

ADAMKOVÁ, J., K. HENSEL, A. GREŠKOVÁ, M. KLOZÍK, M. LEHOTSKÝ, H. OTAHELOVÁ, F. ŠPORKA, E. ŠTEFKOVÁ \& M. VALACHOVIC, 2004. Príprava databázy hydromorfologických a biologických ukazovatel'ov pre proces výberu a charakterizácie referenčných miest podl'a Smernice 2000/60/EC (English: Hydromorphological 
River Survey and Assessment (Slovakia)). Report to SHMI, Bratislava, Slovakia. 16 pp.

AQUAPLUS, POVODÍ LABE, MINISTERSTVO ZEMĚDĚLSTVÍČR \& DHI HYDROINFORM, 2004. Silně ovlivněné vodní útvary. Metody a jejich využití v prrípadové studii $\mathrm{v}$ povodí Labe, Česká republika. Verze 4.0. http://heis.vuv.cz/data/ spusteni/projekty/ramcovasmernice/dokumenty/cz/ CZ_HMWB_1.pdf

BROOKES, A. 1988. Channelized rivers: Perspectives for environmental management. Chichester: Wiley. $232 \mathrm{pp}$.

CIS. 2003. Identification and designation of heavily modified and artificial water bodies. Policy summary to the HMWB \& AWB guidance document. CIS Working Group 2.2. 11 pp.

CEN. 2002. A guidance standard for assessing the hydromorphological features of rivers. CEN TC 230/ WG 2/TG 5: N32. May 2002. 21 pp.

EEA. 2010. The European Environment state and outlook 2010. Copenhagen. $36 \mathrm{pp}$.

EISELTOVÁ, M. (ed.), 2010. Restoration of Lakes, Streams, Floodplains, and Bogs in Europe. Springer. Dordrecht. 374 pp.

EUROPEAN COMMISSION (EC). 2000. Directive 2000/60/EC of the European Parliament and of the Council of 23 October 2000 establishing a framework for Community action in the field of water policy. Official Journal of the European Communities, L327: 1-77.

FERNÁNDEZ GONZÁLEZ, D., J. BARQUÍN ORTIZ \& P. J. RAVEN. 2011. A review of habitat assessment methods for rivers; indices or characterization protocols? Limnetica, 30(2): 217-234.

FUKSA, K. J. 2000. Unifikace metod hydroekologického hodnocení toků a niv s pilotní aplikací na úsecích Labe. Závěrečná zpráva úkolu 1003. VÚV T.G.M., Praha. 101 pp.

KAMP, U., W. BINDER \& K. HOELZL, 2005. River habitat monitoring and assessment in Germany. Environmental monitoring and assessment, 127: 209-226.

KAMPA, E. \& W. HANSEN, 2004. Heavily modified water bodies. Springer. $321 \mathrm{pp}$.

KERN, K., T. FLEISCHHACKER, M. SOMMER \& M. KINDE, 2002. Ecomorphological survey of large rivers-Monitoring and assessment of physical habitat conditions and its relevance to biodiversity. Large Rivers, 13(1-2): 1-28.

LAWA 2002. Gewässerstrukturgütekartierung in der Bundesrepublik Deutschland-Übersichtsverfahren.
Empfehlungen Oberirdische Gewässer. Entwurf April 2002. Länderarbeitsgemeinschaft Wasser.

LANGHAMMER, J. \& M. MATOUŠKOVÁ, 2006. Mapping and analysis of river network modification as a factor of flood risk in the Blanice river basin. Geografie, Sborník ČGS, 111(3): 274-291.

MATOUŠKOVÁ, M. 2003. Ekohydrologický monitoring vodnich toku jako podklad pro revitalizaci vodnich ekosystému. Ph.D. Thesis, Department of Physical Geography and Geoecology, Faculty of Science, Charles University in Prague. Prague. $218 \mathrm{pp}$.

MATOUŠKKOVÁ, M. 2007. Závěrečná zpráva z grantu GAČR 205/05/P102. Faculty of Science, Charles University in Prague. January 2008, http:// Www.gacr.cz., $10 \mathrm{pp}$.

MATOUŠKOVÁ, M. 2008a. Assessment of the river habitat quality within European Water Framework Directive: Application to different catchments in Czechia. Geografie, Sborník ČGS, 113(3): 223 236.

MATOUŠKOVÁ, M. (ed.) 2008b. Ekohydrologický monitoring vodních ekosystémů v kontextu Rámcové směrnice o vodní politice EC/2000/60. Faculty of Science, Charles University in Prague. 209 pp.

MATOUŠKOVÁ, M., A. WEISS \& J. MATSCHULLAT, 2010. Ecological survey of river habitat diversity: trans-boundary cooperation in the Ore Mountains (Krušné hory, Erzgebirge). Geografie, Sborník ČGS, 115(3): 284-307.

PEDERSEN, M. L., N. B. OVESEN, G. N. FRIBER, B. CLAUSEN, M. LEHOTSKÝ \& A. GRESKOVÁ, 2004. Hydromorphological assessment protokol for the Slovak republic. ANNEX 1. www. shmu.sk/File/implementacia_rsv/twinning/a1_Protocol_final.pdf.

PAUL, M. J. \& J. L. MEYER. 2001. Streams in the urban landscape. Annual Review of Ecology and Systematics, 32: 333-365.

POVODÍ OHŘE, s.p., 1986. Významná vodohospodřářská díla povodí Ohře. Nakladatelství technické literatury. Praha. $167 \mathrm{pp}$.

QUITT, E. 1971. Klimatické oblasti Československa. Studia geografica 16. Academia, Praha. 73 pp.

SCHNEIDER, E. 2010. Floodplain Restoration of Large European Rivers, with Examples from the Rhine and the Danube. In: Restoration of Lakes, Streams, Floodplains and Bogs in Europe: Principles and Case Studies. M. Eiseltova. (ed.): 185224. Wetlands: Ecology, Conservation and Man- 
agement, 3. Springer Science + Busines Media, Dordrecht.

SEMENIUK, V. 1997. The linkage between biodiversity and geodiversity. In: Pattern and process: Towards a regional approach to national estate assessment of geodiversity. R. Eberhard (ed.): 51-58. Technical Series No. 2. Australian Heritage Commission \& Evironment Forest Taskforce, Environment Australia, Canberra.

TOLASZ, R. (ed.) 2007. Atlas podnebí ČR. ČHMÚ, Praha. $256 \mathrm{pp}$.

ŠÍPEK, V., MATOUŠKOVÁ \& M. DVOŘÁK, 2010.

Comparative analysis of selected hydromorpho- logical assessment methods. Environmental Monitoring Assessment, 169: 309-319.

VLASÁK, P. 2004. Ekologická studie Bíliny. VÚV T.G.M., Praha. 35 pp.

WEISS, A., M. MATOUŠKOVÁ \& J. MATSCHULLAT, 2008. Hydromorphological assessment within the EU-Water Framework Directive-Transboundary cooperation and application in to different water basins. Hydrobiologica, 603, 1: 53-72.

XIA, T., W. ZHU, P. XIN \& L. LI. 2010. Assessment of urban stream morphology: an integrated index and modeling system. Environmental Monitoring Assessment, 167: 447-460. 
